\title{
A Changing Pattern of Brain-Derived Neurotrophic Factor Expression Correlates with the Rearrangement of Fibers during Cochlear Development of Rats and Mice
}

\author{
Barbara Wiechers, ${ }^{1}$ Glikeria Gestwa, ${ }^{1}$ Andreas Mack, ${ }^{2}$ Patrick Carroll,, ${ }^{3}$ Hans-Peter Zenner, ${ }^{1}$ and \\ Marlies Knipper ${ }^{1}$
}

Departments of ${ }^{1}$ Oto-Rhino-Laryngology and ${ }^{2}$ Anatomy, University of Tübingen, D-72076 Tübingen, Germany, and 3/nstitut National de la Santé et de la Recherche Médicale, Institut National de la Santé et de la Recherche Médicale, Unit 382, 13288 Marseille Cedex 09, France

The reorganization of specific neuronal connections is a typical feature of the developing nervous system. It is assumed that the refinement of connections in sensory systems requires spontaneous activity before the onset of cochlear function and selective sensory experience during the ensuing period. The mechanism of refinement through sensory experience is currently postulated as being based on the selective reinforcement of active projections by neurotrophins. We studied a presumed role of neurotrophins for rearrangement of afferent and efferent fibers before the onset of sensory function in the precisely innervated auditory end organ, the cochlea. We observed a spatiotemporal change in the localization of brain-derived neurotrophic factor (BDNF) protein and mRNA, which correlated with the reorganization of fibers. Thus, BDNF decreased in

Activity-dependent rearrangement of fibers is a general property of the developing nervous system commonly studied in the visual cortex and in neuromuscular junctions (Van Essen et al., 1990; Hockfield and Kalb, 1993; Cramer and Sur, 1995). In the visual system, the refinement of patterning, subsequent to the onset of visual function, is presumed as being primarily dependent on visual experience (Antonini and Stryker, 1993) and as being influenced by neurotrophins (Cabelli et al., 1995; Kwon and Gurney, 1996).

Neurotrophins, including nerve growth factor (NGF), brainderived neurotrophic factor (BDNF), neurotrophin-3 (NT-3), and neurotrophin-4 (NT-4), act through their appropriate highaffinity receptors trkA, trkB, and trkC (for review, see Bothwell, 1991), as well as through the low-affinity neurotrophin receptor p75 NGFR (Chao, 1994). In addition to their role as mediators of selective neuronal survival (Barde, 1989), neurotrophins have potent abilities for enhancing the efficacy of synaptic transmission (Lohof et al., 1993; Knipper et al., 1994a,b; Kang and Schuman, 1995; Figurov et al., 1996), as well as for influencing the pattern-

\footnotetext{
Received Aug. 3, 1998; revised Feb. 2, 1999; accepted Feb. 8, 1999.

This work was supported by Deutsche Forschungsgemeinschaft Grants Ze 149/ 6-1, Kni 316/2-1, and SFB 430/Kni-B3. We thank Hans Thoenen (Max-PlanckInstitut, Martinsried, Munich, Germany) for the generous supply of BDNF mutant mice. Furthermore, we thank Regeneron Pharmaceuticals, Inc. (Tarrytown, NY) for placing cDNA probes of BDNF and trkB at our disposal.

Drs. Wiechers and Gestwa contributed equally to this work.

Correspondence should be addressed to Dr. Marlies Knipper, University of Tübingen, Department of Oto-Rhino-Laryngology, Laboratory of Molecular Neurobiology, Röntgenweg 11, D-72076 Tübingen, Germany.

Copyright (C) 1999 Society for Neuroscience $\quad 0270-6474 / 99 / 193033-10 \$ 05.00 / 0$
}

target hair cells during fiber retraction and was subsequently upregulated in neurons, target hair cells, and adjacent supporting cells concomitant with the formation of new synaptic contacts. Analysis of the innervation pattern in BDNF gene-deleted mice by immunohistochemistry and confocal microscopy revealed a failure in the rearrangement of fibers and a BDNF dependency of distinct neuronal projections that reorganize in control animals. Our data suggest that, before the onset of auditory function, a spatiotemporal change in BDNF expression in sensory, epithelial, and neuronal cells may guide the initial steps of refinement of the innervation pattern.

Key words: BDNF; fiber rearrangement; innervation pattern; cochlea; development; rat; knock-out mouse ing and stability of synaptic contacts (Cabelli et al., 1995; Wang et al., 1995).

Before the onset of auditory function, spontaneous activity contributes to the development of orderly connections (Meister et al., 1991; Penn et al., 1994; for review, see Shatz, 1996). The mechanisms that determine the selectivity of the early reorganization of fibers are still unknown. In the cochlea, a rearrangement of nerve projections occurs before the onset of hearing. At the outer hair cell (OHC) level, transitory radial afferent type I collaterals retract and are exchanged by spiral afferents type II and efferents from the medial olivocochlear complex (MOC efferents) (Lenoir et al., 1980; Hafidi and Romand, 1989; Sobkowicz, 1992; Knipper et al., 1995). At the inner hair cell (IHC) level, efferents originating in the lateral olivocochlear complex (LOC efferents) lose their contacts with the soma and form new synapses with dendrites of afferent type I fibers, which project to IHCs (Lenoir et al., 1980; Pujol, 1986; Echteler, 1992).

Manifold studies demonstrated the crucial role of BDNF and NT-3 for the survival of the distinct sets of cochlea neurons (Pirvola et al., 1994; Ernfors et al., 1995; Fritzsch et al., 1997). Recently, a transient expression of the neurotrophin receptor trkB in hair cells has been observed during the rearrangement of fibers (Knipper et al., 1996, 1997). To elucidate the presumed functional involvement of trkB ligand BDNF in the reorganization of connectivities before auditory experience, we analyzed the BDNF expression in postnatal rat and mice cochlea and correlated our results with the rearrangement of fibers in control and BDNF null mutant mice. 


\section{MATERIALS AND METHODS}

Animals. Wistar rats were purchased from Interfauna (Tuttlingen, Germany). BDNF +/- mice, heterozygous for a deletion of the BDNF gene, were kindly provided by Patrick Carroll and Hans Thoenen (MaxPlanck-Institut, Martinsried, Munich, Germany). BDNF - /- null mutant mice were obtained by mating of heterozygous mice. The offspring was genotyped by PCR according to Korte et al. (1995). Homozygous $+/+$ littermates were used as controls.

Tissue preparation. BDNF $+/+$ and $-/-$ mice and Wistar rat pups of ages postnatal day 1 (P1) to $\mathrm{P} 17$ were used for this study. The day of birth was defined as P0. Cochleae were prepared as described by Knipper et al. (1997). Tissues were cryosectioned at $10 \mu \mathrm{m}$ for in situ hybridization and immunohistochemistry and at $25 \mu \mathrm{m}$ for laser scanning confocal microscopy and stored at $-20^{\circ} \mathrm{C}$. For mRNA and protein preparations, tissues were immediately frozen in liquid nitrogen and stored at $-70^{\circ} \mathrm{C}$ before use.

Immunohistochemical staining for fluorescence microscopy. For staining with rabbit polyclonal anti-BDNF antibody $(2 \mu \mathrm{g} / \mathrm{ml}$; Chemicon, Temecula, CA), rat cochlea sections were permeabilized with $0.1 \%$ saponin

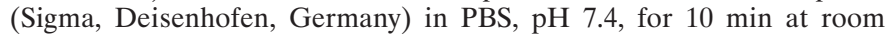
temperature and blocked with $5 \%$ goat serum in PBS before overnight incubation with antibody at $4^{\circ} \mathrm{C}$. For neutralization of BDNF immunoreaction, the anti-BDNF antibody was preincubated with either recombinant human BDNF (rhBDNF) (100 ng/ml; Regeneron Pharmaceuticals, Tarrytown, NY) or recombinant human NT-3 (rhNT-3) (100 ng/ml; Regeneron Pharmaceuticals) before immunohistochemical staining. Mouse cochlea sections were permeabilized with $0.1 \%$ Triton X-100 in PBS, blocked with $1 \%$ bovine serum albumin in PBS, and incubated overnight at $4^{\circ} \mathrm{C}$ with monoclonal antibody to GAP-43 (1:50, clone GAP-7B10; Sigma) or rabbit polyclonal antibodies to GluR4 (1:50; Chemicon), GluR2/3 (1:50; Chemicon), NF-200 (1:1000; Sigma), or synaptophysin (1:10; Chemicon). Primary antibodies were detected with Cy3- $(0.35 \mu \mathrm{g} / \mathrm{ml}$; Jackson ImmunoResearch, West Grove, PA) or FITCconjugated secondary antibodies (1:100; Sigma). Sections were mounted with Vectashield (Vector Laboratories, Burlingame, CA) and viewed using an Olympus (Tokyo, Japan) AX70 microscope equipped with epifluorescence illumination.

Immunohistochemical staining for laser scanning confocal microscopy. Sections (25- $\mu \mathrm{m}$-thick) of BDNF $+/+$ and $-/-$ mice were immunostained with rabbit polyclonal anti-synaptophysin antibody (1:10; Chemicon) and Cy3-conjugated secondary antibody $(0.35 \mu \mathrm{g} / \mu \mathrm{l}$; Jackson ImmunoResearch). Sections were viewed using a confocal laser scanning microscope [Zeiss (Oberkochen, Germany) LSM 410 with an Axiovert $135 \mathrm{M}$ ]. Stacks of images $0.5 \mu \mathrm{m}$ apart were taken on the $z$-axis of the hair cells and reconstructed using VoxelView software (Vital Images, Fairfield, IA).

Western blot analysis. Cochleae were collected from postnatal rats and mice, homogenized in electrophoresis sample buffer $(250 \mathrm{~mm}$ Tris-HCl, pH $6.8,15 \%$ sodium dodecylsulfate, $40 \%$ sucrose, 5 mM EDTA, and $15 \%$ $\beta$-mercaptoethanol), and heated at $90^{\circ} \mathrm{C}$ for $5 \mathrm{~min}$. The protein equivalent of four (rats) or six (mice) cochlea and recombinant human neurotrophins (Regeneron Pharmaceuticals) were separated on $15 \%$ acrylamide gels, and the protein was transferred to $0.2 \mu \mathrm{m}$ nitrocellulose membranes (Amersham, Buckinghamshire, UK) as described by Towbin et al. (1979). Membranes were blocked with 5\% dry milk powder in PBS and incubated with anti-BDNF antibody ( $1 \mu \mathrm{g} / \mu \mathrm{l}$; Chemicon). Bound antibodies were visualized with the enhanced chemiluminescence detection system (Amersham).

Riboprobe synthesis. pBluescript II SK(-) vectors containing fulllength sequences of rat trkB (pSK-rTrkB(C1); $3.3 \mathrm{~kb})$ and rat BDNF (pSK-rB(C1); $1.1 \mathrm{~kb})$ were supplied by Regeneron Pharmaceuticals. Complementary strands for sense or antisense were transcribed from T7 or T3 promotor sites in the presence of digoxigenin labeling mix (Boehringer Mannheim, Mannheim, Germany) to obtain labeled riboprobes or, in the presence of nonlabeled nucleotide triphosphates, to obtain nonlabeled riboprobes. Nonlabeled RNA probes were used in cohybridization assays to test the specificity of the riboprobes.

In situ hybridization. Riboprobes were diluted to appropriate concentrations in hybridization buffer (RPN3310; Amersham) containing 50\% formamide and were denatured for $10 \mathrm{~min}$ at $68^{\circ} \mathrm{C}$. Riboprobes were applied to sections for overnight hybridization in a $50 \%$ formamide chamber at $55^{\circ} \mathrm{C}$. Sections were washed twice in $0.1 \times \mathrm{SSC}(300 \mathrm{~mm}$ sodium chloride and $30 \mathrm{~mm}$ sodium citrate, $\mathrm{pH} 7.0$ ) at $55^{\circ} \mathrm{C}$ for $30 \mathrm{~min}$. To analyze the specificity of the riboprobes, digoxigenin-labeled riboprobes were cohybridized with a 100-fold excess of a nonlabeled ribo-

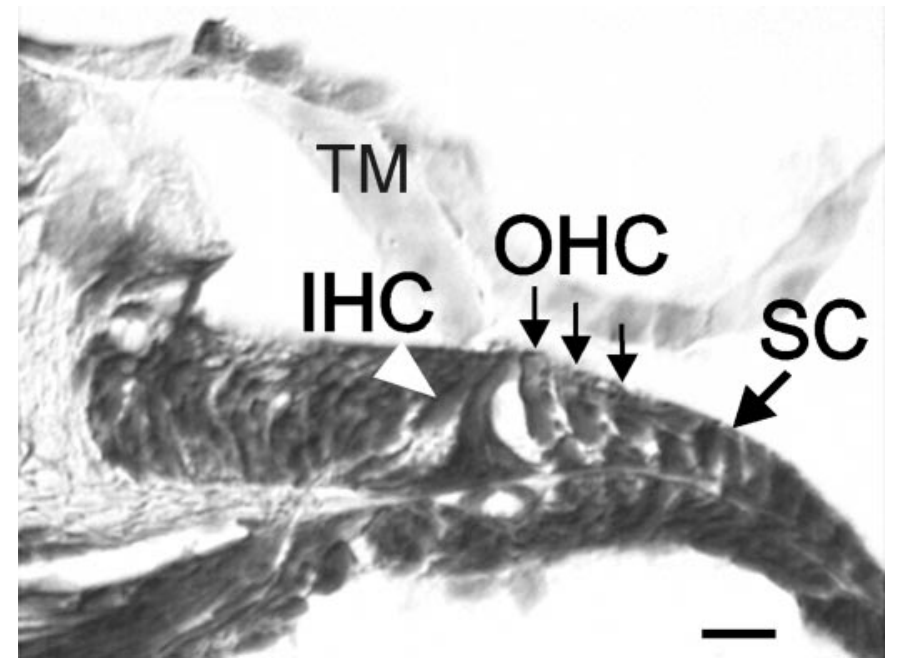

Figure 1. Toluidine blue stained section of an organ of Corti of a mouse at P5, indicating the typical cellular details of an organ at that age. $S C$, Supporting cells; $T M$, tectorial membrane. Scale bar, $20 \mu \mathrm{m}$.

probe of the same or the related gene. After a brief wash in Tris buffer $(0.1 \mathrm{M}$ Tris- $\mathrm{HCl}$ and $0.15 \mathrm{M}$ sodium chloride, $\mathrm{pH} 7.5)$, sections were blocked in Tris buffer containing $0.5 \%$ blocking reagent (catalog \#1096176; Boehringer Mannheim) and 0.3\% Triton X-100 and incubated with anti-digoxigenin antibody conjugated to alkaline phosphatase (1:750; Boehringer Mannheim). Sections were exposed to staining solution containing nitroblue tetrazolium salt and 5-bromo-4-chloro-3indolyl phosphate for up to $20 \mathrm{hr}$ and viewed with Normarski optics using an Olympus AX70 microscope.

\section{RESULTS}

\section{Spatiotemporal expression pattern of BDNF in the developing cochlea}

In a first step, we studied the spatiotemporal expression of BDNF protein in mice and rat cochlea (data not shown) during the first 2 postnatal weeks by immunohistochemistry. The alteration of the expression profile of BDNF was found to be similar in both species. In mice, however, all processes occurred $\sim 1$ or $2 \mathrm{~d}$ in advance to rats. For a better understanding of the specific terms used to describe the cellular structures in the organ of Corti during this time, see Figure 1, which illustrates the typical morphological and cellular details of a postnatal organ of Corti, shown for mice cochlea. At P1, BDNF was expressed in hair cells in the more apical, but not basal, cochlea turns, as shown for the medial turn in Figure 2 (P1, Organ of Corti, IHC, OHC). No BDNF expression was detected in spiral ganglion cells (Fig. 2, P1, Spiral Ganglion). Between P2 and P4, BDNF was absent in the organ of Corti in the apical to basal cochlea turn (Fig. 2, P3, Organ of Corti). During this time, BDNF gradually appeared in distinct spiral ganglion cells, as shown for P3 (Fig. 2, P3, Spiral Ganglion). At approximately P5-P6, the number of immunopositive spiral ganglion neurons reached a maximum and, in addition to cell bodies, neuronal projections were BDNF-immunopositive (Fig. 2, P6, Spiral Ganglion). These immunopositive fibers seemed to be afferents but not efferents, because BDNF was not detected in the intraganglionic spiral bundle (data not shown). From P4 onward, BDNF reappeared in the organ of Corti of the apical to midbasal, but not basal, cochlea turn. BDNF appeared in outer hair cells and supporting cells that are in contact with hair cells as pillar, Deiters', and border cells (Fig. 2, P6, Organ of Corti). Whereas BDNF expression persisted in Deiters' and border cells at least 


\section{Spiral Ganglion}
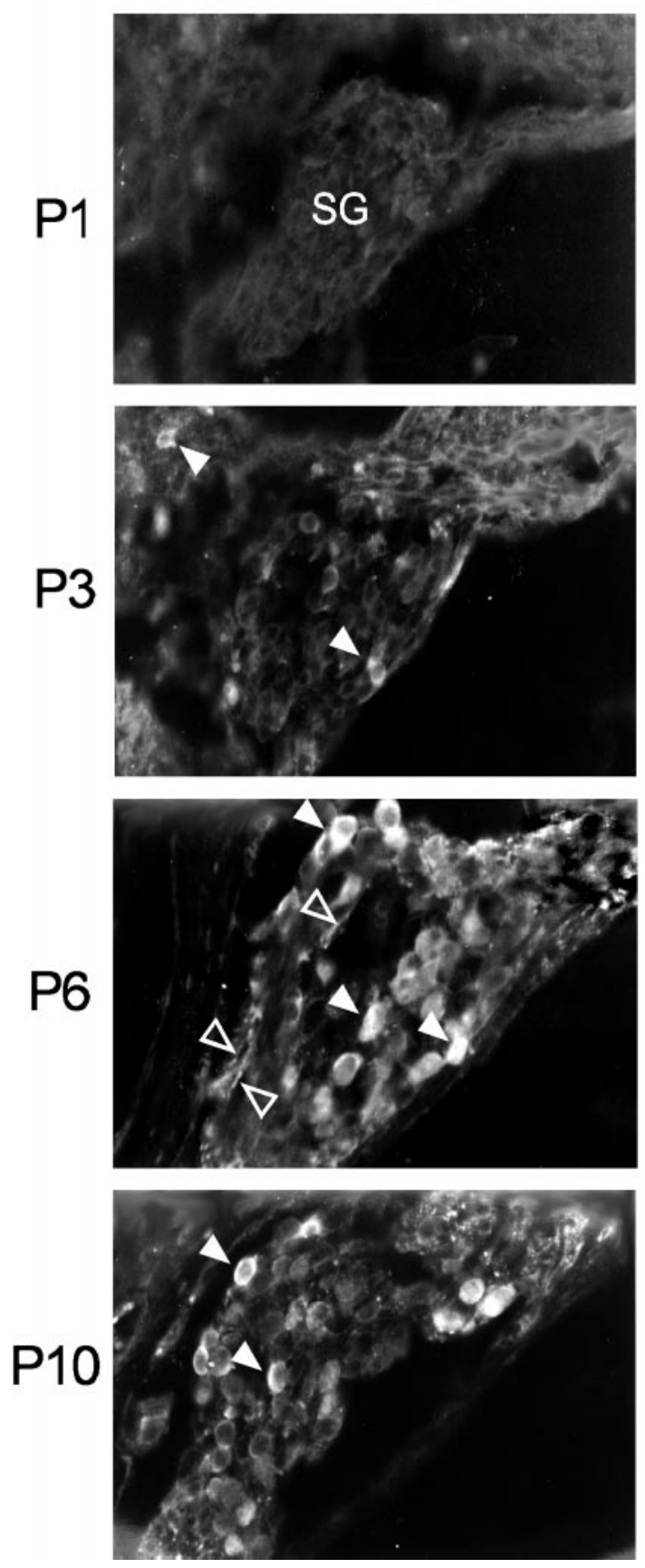

\section{Organ of Corti}
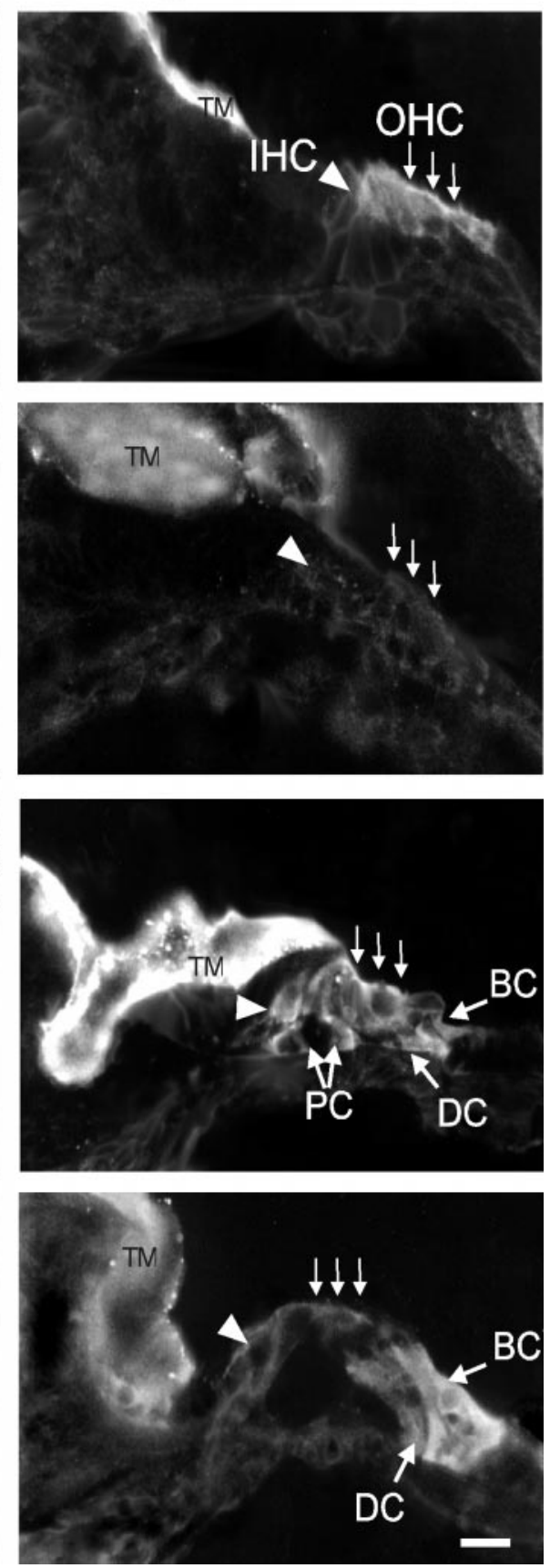

Figure 2. Localization of BDNF protein in spiral ganglion cells and organ of Corti in mice cochleae (BDNF $+/+$ ) at P1, P3, P6, and P10 by immunohistochemistry. In IHCs (arrowhead) and OHCs (vertical arrows) of the organ of Corti, BDNF was expressed at P1, was absent at $\mathrm{P} 3$, reappeared at $\mathrm{P} 6$, and was downregulated again at P10. At P6, BDNF was also detected in supporting cells as pillar cells $(P C)$, Deiters' cells $(D C)$, and border cells $(B C)$. In the spiral ganglion $(S G)$, no BDNF staining was detected at P1, single neurons expressed BDNF at P3 (arrowhead), and the maximal number of immunopositive neuronal cell bodies was reached between P4 and P6 (P6, filled arrowheads). During this time, we observed BDNF in neuronal fibers (P6, open arrowheads). The experiment was repeated in triplicate with similar results. The staining of the tectorial membrane (TM) was nonspecific. Scale bar, $20 \mu \mathrm{m}$. up to P12 (Fig. 2, P6, P10, Organ of Corti), BDNF disappeared from hair and pillar cells from P8 onward, as shown for P10 (Fig. 2, P10, Organ of Corti). Beyond P8, BDNF could no longer be detected in neuronal fibers but only in neuronal cell bodies (Fig. 2, P10, Spiral Ganglion). The antibody to BDNF nonspecifically stained the tectorial membrane (Fig. 2, Organ of Corti, TM). This alteration of the expression pattern of BDNF protein during the first 2 postnatal weeks was observed with similar results in triplicate experiments in mice and rats.

Specificity and sensitivity of the anti-BDNF antibody was examined by immunoblot analysis. The antibody recognized only recombinant BDNF protein but not NT-3, NT-4, or NGF (Fig. $3 A$ ). The minimum amount of rhBDNF detected by the antibody was $5 \mathrm{ng}$ (Fig. 3B). Thus, the anti-BDNF antibody used in the present study did not cross react with neurotrophins other than BDNF and revealed a similar sensitivity as other anti-BDNF antibodies used in previous studies (Zhou und Rush, 1996). In addition, we analyzed the reaction of the anti-BDNF antibody with cochlear proteins (Fig. $3 C$, Cochlea) and used rhBDNF as control (Fig. 3C, rhBDNF). A protein close to the molecular weight of mature BDNF protein was detected in rat cochlea at P5 (Fig. 3C, arrow). Furthermore, proteins of $\sim 20$ and $30 \mathrm{kDa}$ were labeled, which may correspond to the unprocessed precursor proteins of $\mathrm{BDNF}$, and a $\sim 45 \mathrm{kDa}$ protein of unknown identity (Fig. 3C, Cochlea). To further test the specificity of the antibody, we performed preabsorption experiments (Fig. $3 D$ ). BDNF im- 

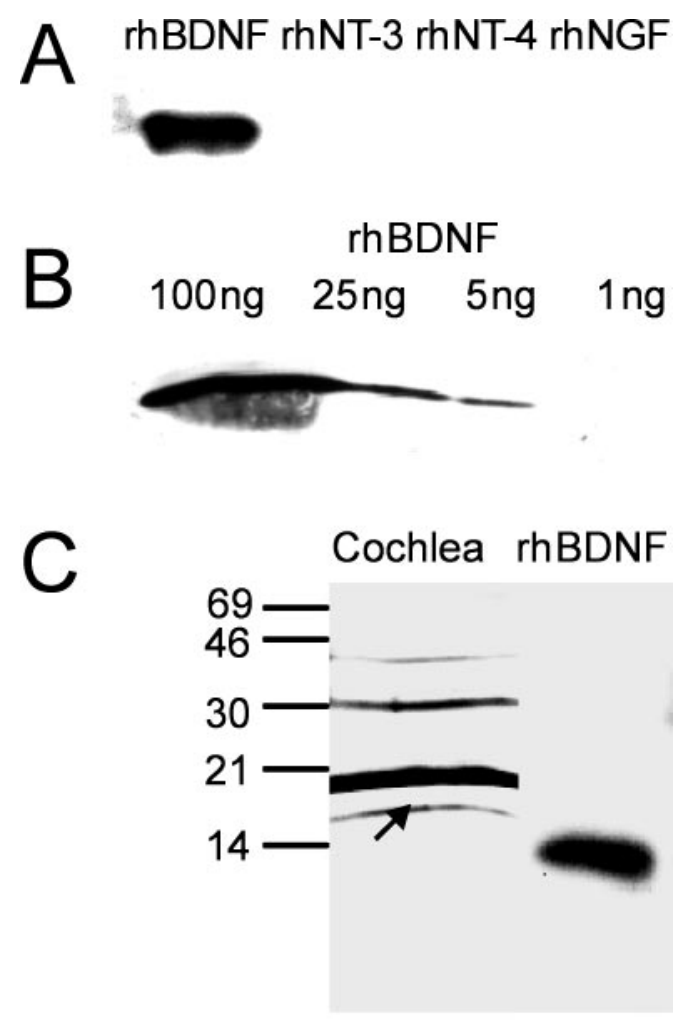

D
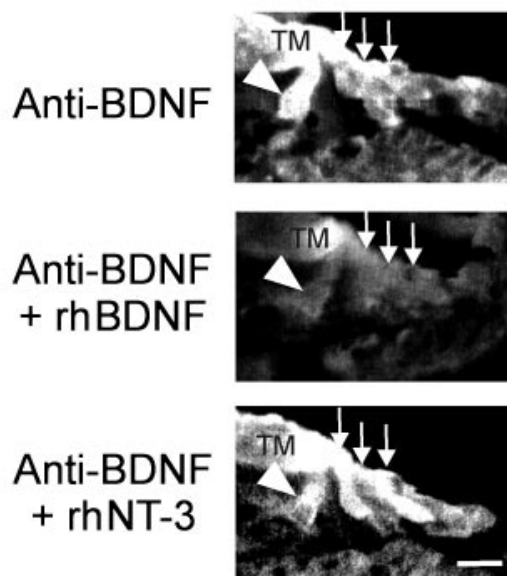

Figure 3. Characterization of anti-BDNF antibody. A, Cross-reactivity of anti-BDNF antibody with neurotrophins NT-3, NT-4, and NGF was tested in Western blot analysis. Anti-BDNF recognized only rhBDNF but not rhNT-3, rhNT-4, or rhNGF. $B$, Sensitivity of anti-BDNF antibody was tested in Western blot using indicated concentrations of BDNF. The minimal amount rhBDNF recognized by anti-BDNF antibody was $5 \mathrm{ng}$. $C$, In a Western blot with rat cochlear protein, anti-BDNF antibody recognized a protein (arrow) close to the molecular weight of rhBDNF, which is likely to be the mature BDNF protein. Anti-BDNF antibody also recognized proteins of $\sim 20$ and $\sim 30 \mathrm{kDa}$, probably BDNF precursor proteins. $D$, Anti-BDNF immunoreaction $($ Anti-BDNF) in hair cells (arrowheads and vertical arrows) was completely abolished by preabsorption of the antibody with rhBDNF (Anti-BDNF+rhBDNF) but not with rhNT-3 (Anti-BDNF+rhNT-3). Immunoreaction in the tectorial membrane (TM) was nonspecific. Scale bar, $20 \mu \mathrm{m}$.

munoreactivity in hair cells of mice (data not shown) and rat (Fig. $3 D$, Anti-BDNF ) cochlea was completely abolished by preincubation of the anti-BDNF antibody with an excess of rhBDNF (Fig. $3 D$, Anti-BDNF+rhBDNF), whereas a preincubation of the anti-
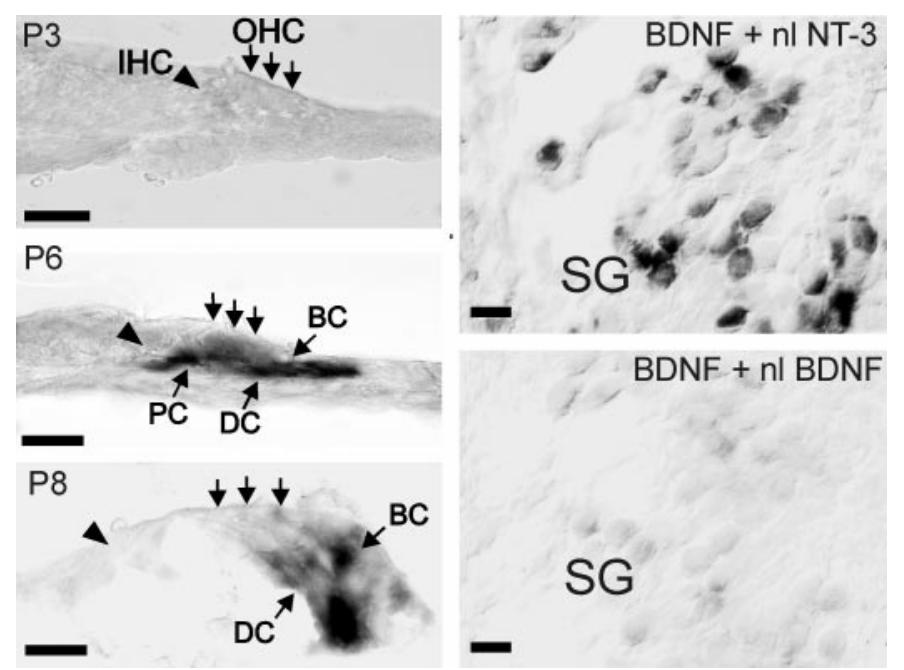

Figure 4. Localization of BDNF mRNA in the organ of Corti and the spiral ganglion of rats by in situ hybridization. Although no BDNF mRNA was detected at P3, BDNF mRNA was localized in OHCs (vertical arrows), pillar cells (PC), Deiters' cells (DC), and border cells $(B C)$ of the organ of Corti at P6. At P8, BDNF mRNA was noted restrictively in Deiters' and border cells. In the spiral ganglion $(S G)$, BDNF hybridization signal in neurons was not effected by cohybridization with an excess of nonlabeled NT-3 antisense $(B D N F+n l N T-3)$ but was completely abolished by cohybridization with an excess of nonlabeled BDNF antisense $(B D N F+n l B D N F)$. Scale bars, $20 \mu \mathrm{m}$.

body with rhNT-3 had no effect on the immunoreactivity (Fig. $3 D$, Anti-BDNF $+r h N T-3)$. The staining of the tectorial membrane was nonspecific (Fig. 3D, TM).

Because the localization of BDNF protein may be caused by either a local BDNF synthesis or by an uptake of BDNF synthesized in other cells, we studied BDNF expression at the mRNA level by in situ hybridization. The distribution of BDNF mRNA was similar in rats and mice and is shown for rats in Fig. 4. Using in situ hybridization, BDNF signals were detected in hair cells of the most apical cochlea turn at P1 only in rats but not in the earlier developed mice (data not shown). The detection of BDNF mRNA at P1 in rats did depend on the size of the litter, with positive results in younger $\mathrm{P} 1$ specimens and negative results in older P1 specimens. From P1 onward, BDNF mRNA was not detected in the organ of Corti, as shown for P3 (Fig. 4, P3, IHC, $O H C$ ), but reappeared in hair and supporting cells as pillar, Deiters', and border cells in mice at approximately P4 (data not shown) and in rats at approximately P5, as shown for P6 (Fig. 4, P6). From P8 onward, BDNF mRNA disappeared from hair and pillar cells but lasted in Deiters' and border cells (Fig. 4, P8, DC, $B C)$. We repeatedly observed that, in rat and mice species, the disappearance of BDNF mRNA precedes the disappearance of BDNF protein by $\sim 1$ or $2 \mathrm{~d}$. The detection of BDNF protein in spiral ganglia cells could also be confirmed on mRNA level $(n>$ 10) (Fig. 4, $S G$ ) and was demonstrated on parallel improvement of the specificity of the BDNF riboprobe. A possible crossreaction of BDNF riboprobe with NT-3 mRNA was scrutinized in competition experiments. BDNF signal was completely abolished by a cohybridization with an excess of nonlabeled BDNF antisense riboprobe (Fig. 4, $S G, B D N F+n l B D N F$ ), whereas an excess of nonlabeled NT-3 antisense did not diminish the intensity of the signal (Fig. 4, $S G, B D N F+n l N T-3$ ). Furthermore, we localized high-affinity neurotrophin receptor trkB mRNA in spiral ganglion neurons during the whole postnatal developmental 

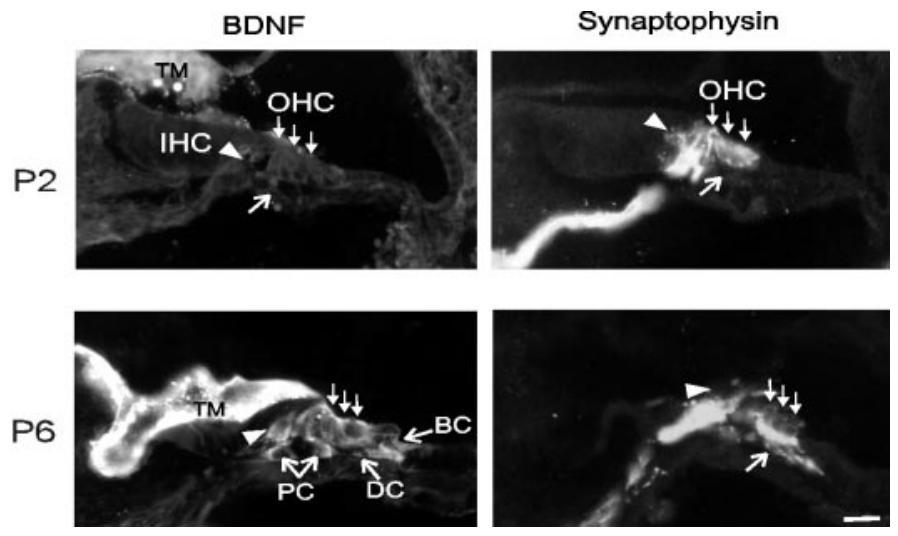

Figure 5. Localization of BDNF protein and synaptophysin protein in the midbasal cochlea turn of mice $(\mathrm{BDNF}+/+)$ by immunohistochemistry. The absence of BDNF protein in the organ of Corti at $\mathrm{P} 2(P 2, B D N F)$ is associated with a detection of synaptophysin-immunopositive presynaptic specializations in $\mathrm{OHC}$ soma ( $P 2$, Synaptophysin). The appearance of BDNF in outer hair cells and supporting cells as pillar cells $(P C)$, Deiters' cells $(D C)$, and border cells $(B C)$ between P4 and P6 occurs parallel to the loss of synaptophysin-immunopositive presynaptic specializations in outer hair cells and the appearance of synaptophysin immunoreactivity in MOC efferents (P6, Synaptophysin). Scale bar, $10 \mu \mathrm{m}$.

period (data not shown). Thus, the spatiotemporal pattern (Fig. 4) of BDNF mRNA expression in the organ of Corti and in the spiral ganglion changed in a manner similar to the expression pattern of BDNF protein (Fig. 2).

\section{Correlation between BDNF expression and rearrangement of fibers}

To scrutinize a possible correlation between BDNF expression and the rearrangement of fibers, we examined the expression of BDNF protein and marker proteins for efferent and afferent projections in control and BDNF gene-deleted mice. We used antibodies to the distinct glutamate receptor subtypes GluR2/3 and GluR4, which are expressed in afferent type I collaterals and afferent type I fibers, respectively (Knipper et al., 1997). We further used antibodies to the $200 \mathrm{kDa}$ neurofilament protein NF-200, which specifically stains afferents (Berglund and Ryugo, 1986;). Furthermore, we used antibodies to the growth-associated protein GAP-43 and to synaptophysin for staining of efferents (Knipper et al., 1995, 1997).

\section{Reorganization of presynaptic specializations at the outer hair cell level}

First, we will focus on the innervation at the OHC level. The analysis of synaptic vesicle proteins in synaptic specializations in hair cells and in efferent fibers at the OHC level was performed using an anti-synaptophysin antibody. In control mice, the absence of BDNF immunoreactivity in hair cells at P2 (Fig. 5, P2, Synaptophysin) was associated with strong synaptophysinimmunoreactive outer hair cells (Fig. 5, P2, Synaptophysin), indicating the existence of presynaptic specializations in OHCs during this time. With the reappearance of BDNF in hair and supporting cells at P4, synaptophysin disappeared from OHCs and appeared in efferent projections opposite to OHCs. This aspect is shown for the basal cochlea turn at P6 for BDNF (Fig. 5, BDNF; see similar illustration in Fig. 2) and synaptophysin (Fig. 5, P6, Synaptophysin). Aiming to clarify the role of BDNF for the reorganization of presynaptic specializations, we studied synaptophysin staining in BDNF gene-deleted mice.

Synaptophysin immunoreactivity in outer hair cells was ob- served in control mice and BDNF gene-deleted mice at P2 (Fig. $6, P 2)$, indicating the existence of presynaptic specializations independent from the presence of BDNF. In control mice, synaptophysin immunoreactivity was lost from the soma of OHCs from P4 onward, when at the same time, synaptophysinimmunoreactive MOC efferents gradually appeared at the base of OHCs, as shown for the midbasal cochlea turn at P6 (Fig. 6, P6, $B D N F+/+$, diagonal arrow). In contrast, in $\mathrm{BDNF}-/-$ mice, synaptophysin-immunoreactive presynaptic specializations were noted in outer hair cells still at P6 and MOC efferents were absent at that time (Fig. 6, P6, BDNF -/-, diagonal arrow). With a delay of $\sim 3 \mathrm{~d}$ (from P8 onward), however, we noticed that synaptophysin declined from $\mathrm{OHCs}$ in $\mathrm{BDNF}-/-$ mice, revealing the reorganization of presynaptic specializations that now occurred coincident with the gradual appearance of MOC efferents. Nevertheless, MOC efferents remained reduced in BDNF $-/-$ mice, even at later developmental stages in comparison to $\mathrm{BDNF}+/+$ mice, as shown for the midbasal cochlea turn at P17 (Fig. 6, P17, diagonal arrow). The BDNF $-/-$ mice exhibited a nearly total destruction of efferents from OHCs in the usually less innervated apical cochlea turns and a retarded efferent innervation of OHCs in the usually more innervated midbasal cochlea turns. In presumptive relation to the near absence of BDNF expression in the most basal cochlea turn, the efferent innervation of OHCs in the basal turn of BDNF $-/-$ mice, however, exhibited an innervation density that was close to normal ( $n=4$; no deviation).

\section{Afferent type I collaterals to outer hair cells}

In BDNF +/+ mice, GluR2/3-immunopositive projections were detected below OHCs until P3 (Fig. 7, P2, GluR2/3, diagonal arrow) but were lost since then, as shown for the medial turn at P6 (Fig. 7, P6, GluR2/3, diagonal arrow). In BDNF - /- mice, however, GluR2/3-immunopositive projections were neither observed at P2 nor at later stages in any cochlea turn, as shown for the medial turn at P6 $(n=3$, without deviation) (Fig. 7, P2, P6, GluR2/3, diagonal arrow), demonstrating the loss of afferent type I collaterals in mutant mice. Considering that the loss of afferent type I collaterals from basal cochlea turns may occur before birth, we cannot exclude, however, that in BDNF $-/-$ mutants some afferent type I collaterals may nevertheless innervate outer hair cells in the basal turn in analogy to a concept of a trophic gradient along the tonotopic axis of the cochlea (Bianchi et al., 1996; Fritzsch et al., 1997).

\section{Afferent type II fibers to outer hair cells}

Afferent type II projections were detected below OHCs in BDNF $+/+$ mice using anti-NF-200 antibody, as shown for P6 and P13 (Fig. 7, $B D N F+/+, N F-200$ ). In BDNF - /- mice, this fiber type was absent at all analyzed ages in the midbasal, medial, and apical turns, although some fibers remained in the basal cochlea turn (data not shown), confirming the data of Bianchi et al. (1996) and Fritzsch et al. (1997). The loss of NF-200-immunopositive afferent type II fibers in the absence of BDNF is shown for the medial turn at P6 and P13 (Fig. 7, BDNF-/-, NF-200). These observations were made in triplicate experiments with similar results.

\section{Efferent fibers to inner hair cells}

BDNF downregulation in inner hair cells and the subsequent BDNF upregulation in spiral ganglion neurons appeared to correlate temporally with the retraction of LOC efferents from the soma of IHC and the formation of new LOC synapses with dendrites of afferents, respectively (Knipper et al., 1995, 1997). We therefore analyzed the innervation at the IHC level during 
Figure 6. Localization of presynaptic specializations in outer hair cells and efferents innervating outer hair cells in the midbasal cochlea turn in control and BDNF gene-deleted mice analyzed by immunohistochemistry using an anti-synaptophysin antibody. At P2, synaptophysin immunoreactivity was observed in BDNF $+/+$ and $-/-$ mice in $\mathrm{OHC}$ soma $(\mathrm{OHC}$, vertical arrows), implicating a BDNF-independent existence of synaptophysin-immunopositive presynaptic specializations in outer hair cells. In control mice at P6, synaptophysin immunoreactivity was restricted to fibers below outer hair cells $(B D N F$ $+/+, P 6, O H C$, vertical arrows), indicating the loss of synaptophysin-immunopositive presynaptic specializations in outer hair cells and the appearance of synaptophysin immunoreactivity in MOC efferents. In BDNF - /- mice, the MOC fiber population was absent at P2 and P6 (BDNF $-1-, \quad P 2, \quad P 6$, diagonal arrow), whereas synaptophysin-immunoreactive presynaptic specializations persisted in outer hair cells at both ages $(P 2, P 6$, vertical arrows $)$. At $\mathrm{P} 17$, presynaptic specializations were lost in BDNF $-/$ - mutants, whereas MOC efferents were still retarded in comparison to controls (compare diagonal arrows below outer hair cells in both specimens at P17). The experiment was repeated in quadruplicate with similar results. Arrowheads, IHC. Scale bar, $20 \mu \mathrm{m}$.

\section{BDNF +/+}
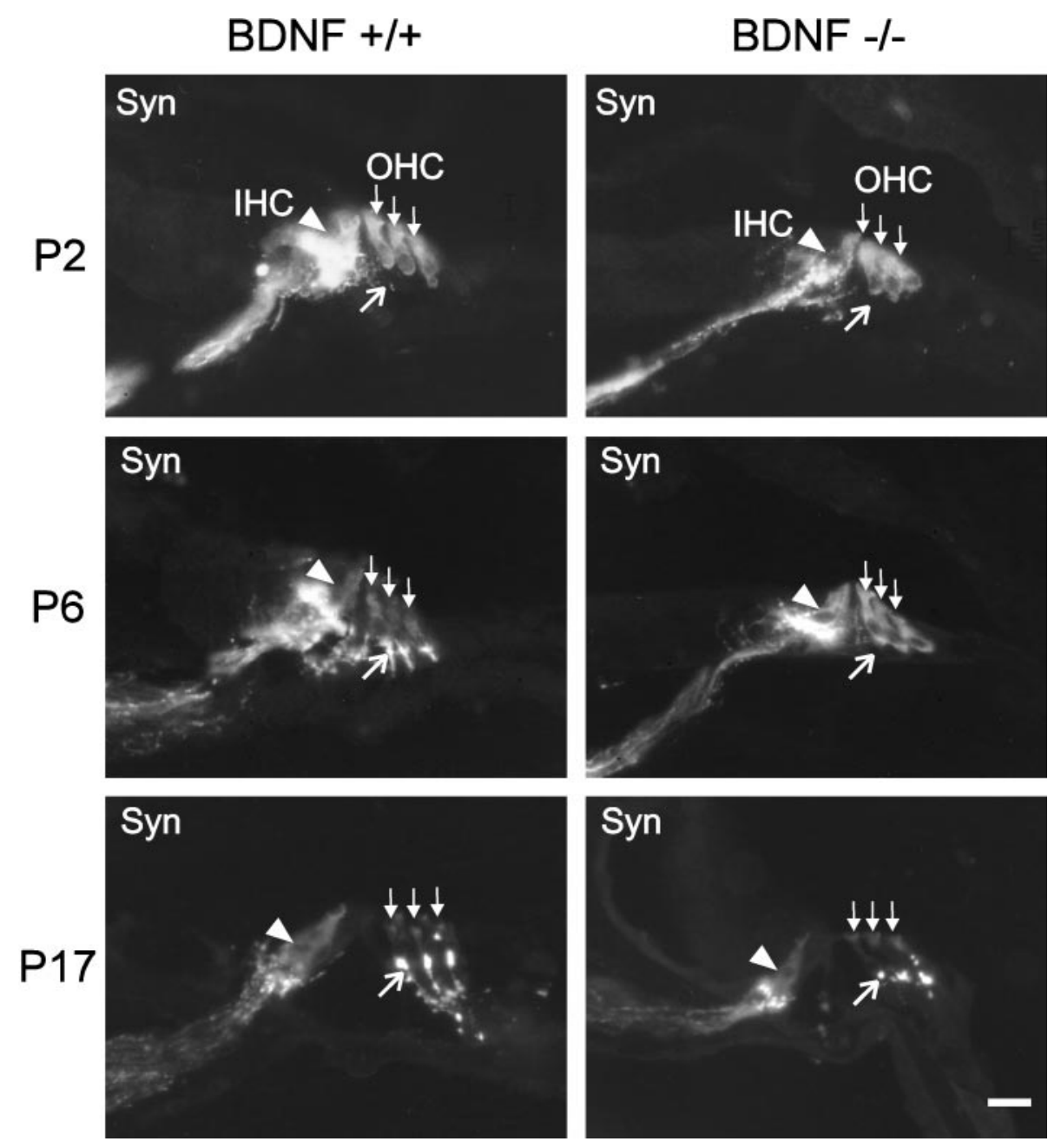

the time of rearrangement of LOC efferents in control and BDNF-deficient mice. Until P3-P4, we could not observe any difference in the innervation pattern of synaptophysin- and GAP43-immunopositive LOC efferents at the base of the IHC in $\mathrm{BDNF}+/+$ and $-/-$ mice, as shown for synaptophysinimmunoreactive LOC efferents in the medial cochlea turn at P4 (Fig. 8A, Syn). From P3-P4 onward, however, in control mice, synaptophysin- and GAP-43-immunopositive LOC efferent synapses gradually moved away from IHC bases to a more distant level, indicating to the switch of LOC synapses to afferent dendrites. This aspect is demonstrated for the GAP-43immunopositive LOC efferents in the medial cochlea at P15, which are localized at that age distant from the IHC soma (Fig. $8 B, B D N F+/+$, asterisks) and distant from double-stained GluR4 receptors in afferent type I fibers at the base of IHCs (Fig. $8 B$, $B D N F+/+$, compare GluR4, GAP-43). In contrast, in BDNF -/- mice, presumptive GAP-43-immunopositive LOC terminals persisted at the base of IHCs ( $n=3$, no deviation) (Fig. $8 B$, $B D N F-/-$, compare GluR4, GAP-43). To obtain more detailed information about a presumed difference of the innervation pattern at the IHC level in control and mutant mice, we analyzed synaptophysin-immunopositive synaptic contacts of LOC efferents below single IHCs by confocal microscopy. In BDNF +/+ mice at P15, a scattered elongated synaptophysin-immunopositive pattern below the IHC was observed (Fig. 8C, BDNF +/+, Syn), whereas in BDNF $-/-$ mice, synaptophysin staining was re- stricted to the base of the IHC ( $n=3$, no deviation) (Fig. $8 C$, $B D N F-/-, S y n)$, confirming the data obtained with anti-GAP-43 antibody at that age (Fig. $8 B$ ).

\section{DISCUSSION}

The data in the present study demonstrate a remarkable change in the expression pattern of BDNF protein (Fig. 2) and mRNA (Fig. 4) in the auditory end organ in mice and rats. Using a highly specific and sensitive antibody (Fig. 3), we observed a decrease of BDNF protein from inner and outer hair cells at approximately $\mathrm{P} 1$, followed by a reappearance of BDNF in hair cells and supporting cells as pillar, Deiters', or border cells at approximately P4 (mice) and P5 (rats), respectively. A successive downregulation of BDNF from hair cells and pillar cells is noted at approximately P8-P9 (Fig. 2).

The early downregulation of BDNF from hair cells at P1 agrees with the results of Wheeler et al. (1994), who quantitatively analyzed BDNF expression in the organ of Corti at the mRNA level. Furthermore, BDNF mRNA expression in outer hair cells of 1-week-old rats was reported by Ylikoski et al. (1993) but was not detected by Wheeler et al. (1994). The unusual downregulation and upregulation of BDNF reported in the present study could have been overlooked in less detailed analyses and may explain current variations in the documented expression pattern of BDNF mRNA in the organ of Corti in the postnatal rat cochlea. 


\section{$\mathrm{BDNF}+/+$}
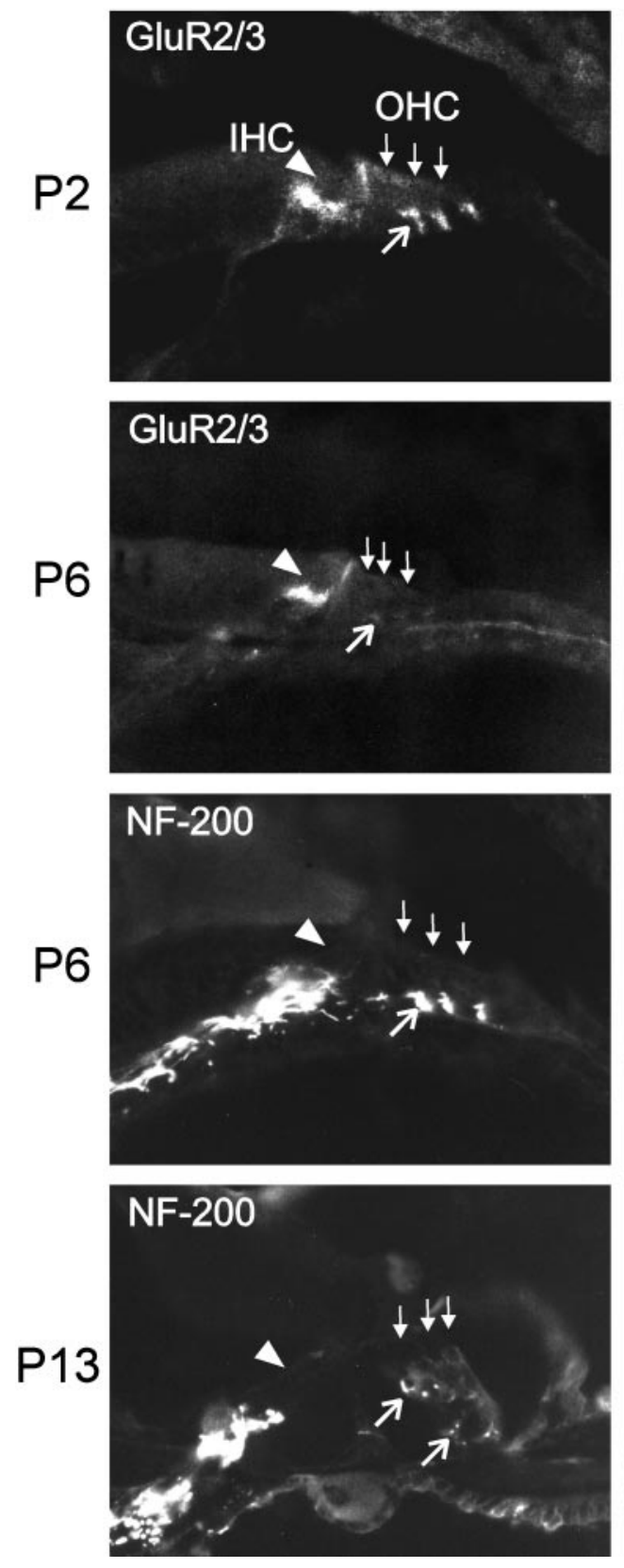

\section{BDNF -/-}
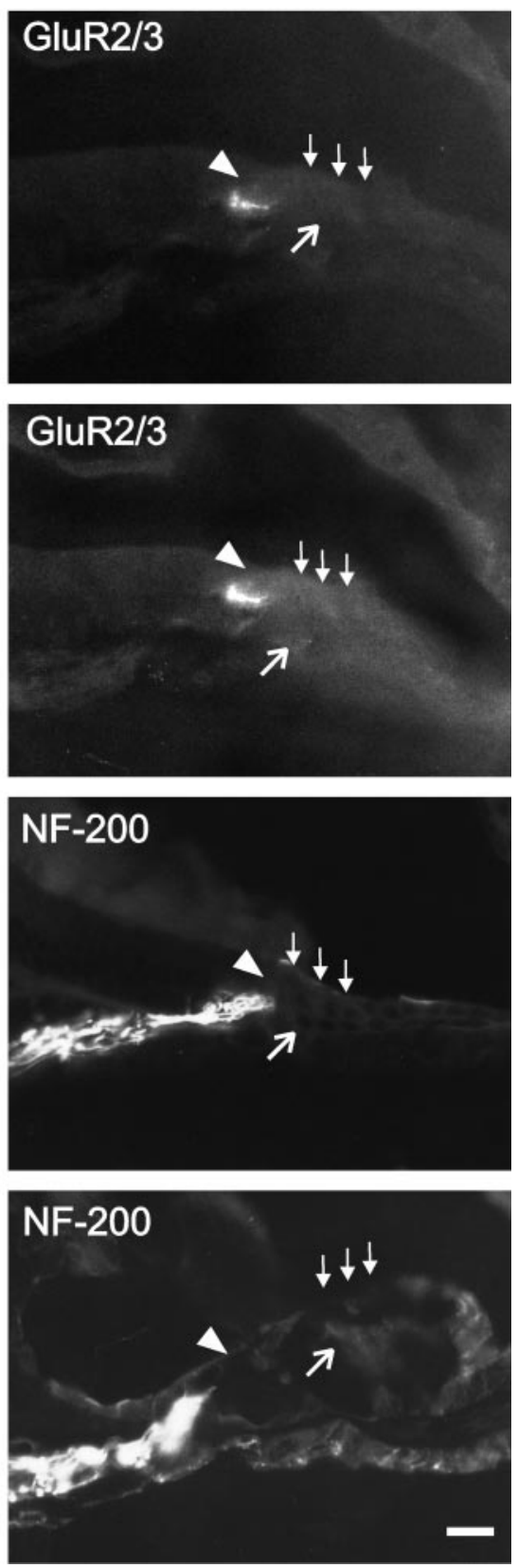

Figure 7. Afferent innervation of outer hair cells in the medial turn of control and BDNF gene-deleted mice analyzed by immunohistochemistry. GluR2/3-immunopositive fibers, presumptive afferent type I collaterals, were observed below outer hair cells in BDNF $+/+$ mice at $\mathrm{P} 2$ but not at $\mathrm{P} 6(B D N F+/+$, GluR2/3, $O H C$, diagonal arrows). These GluR2/3immunoreactive fibers were absent in BDNF $-/-$ mice at both ages (BDNF -/-, GluR2/3, diagonal arrows). Anti-NF-200 stained presumptive afferent type II projections to $\mathrm{OHCs}$ in $\mathrm{BDNF}+/+$ mice at $\mathrm{P} 6$ and $\mathrm{P} 13(B D N F+/+$, $N F-200$, OHC, diagonal arrows), whereas BDNF $-/-$ mice lacked this fiber population at both postnatal ages $(B D N F-/-, N F-200, O H C$, diagonal arrows). The experiment was repeated in triplicate with similar results. Arrowheads, IHC. Scale bar, $20 \mu \mathrm{m}$.
During the downregulation of BDNF in hair cells, we also observed an upregulation of BDNF in spiral ganglion cells. BDNF expression has not yet been described for spiral ganglion neurons but has been reported for other sensory neurons during development (for review, see Davies and Wright, 1995). In addition, as with recent findings in the vestibular system (Montcouquiol et al., 1998), BDNF was expressed in supporting cells of the organ of Corti.

\section{Correlation of BDNF expression with the change in innervation pattern}

When the spatiotemporal change of BDNF expression was compared with the course of the reorganization of early connectivities in the cochlea of control and BDNF gene-deleted animals, a causal relationship between the alteration of the expression pat- tern and the refinement of connectivities became evident. This is discussed in the following.

\section{Reorganization of presynaptic specializations at the outer hair cell level}

The upregulation of BDNF in OHCs in mice cochlea at approximately P4 occurred simultaneously with the disappearance of presynaptic specializations from $\mathrm{OHCs}$ and the synaptogenesis of MOC efferents (Fig. 5). In BDNF gene-deleted mice, MOC efferents formed synaptic contacts with OHCs (Ernfors et al., 1995), indicating that other trophic factors regulate this process. Considering the reported expression profile of the glial-derived nerve growth factor during this time period (Ylikoski et al., 1998), this factor may be an interesting candidate for the control of MOC synaptogenesis. As shown in the present study, however, 
A $\quad$ BDNF $+/+$

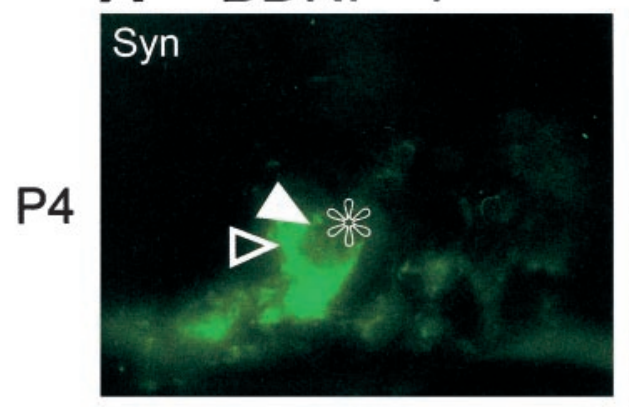

B
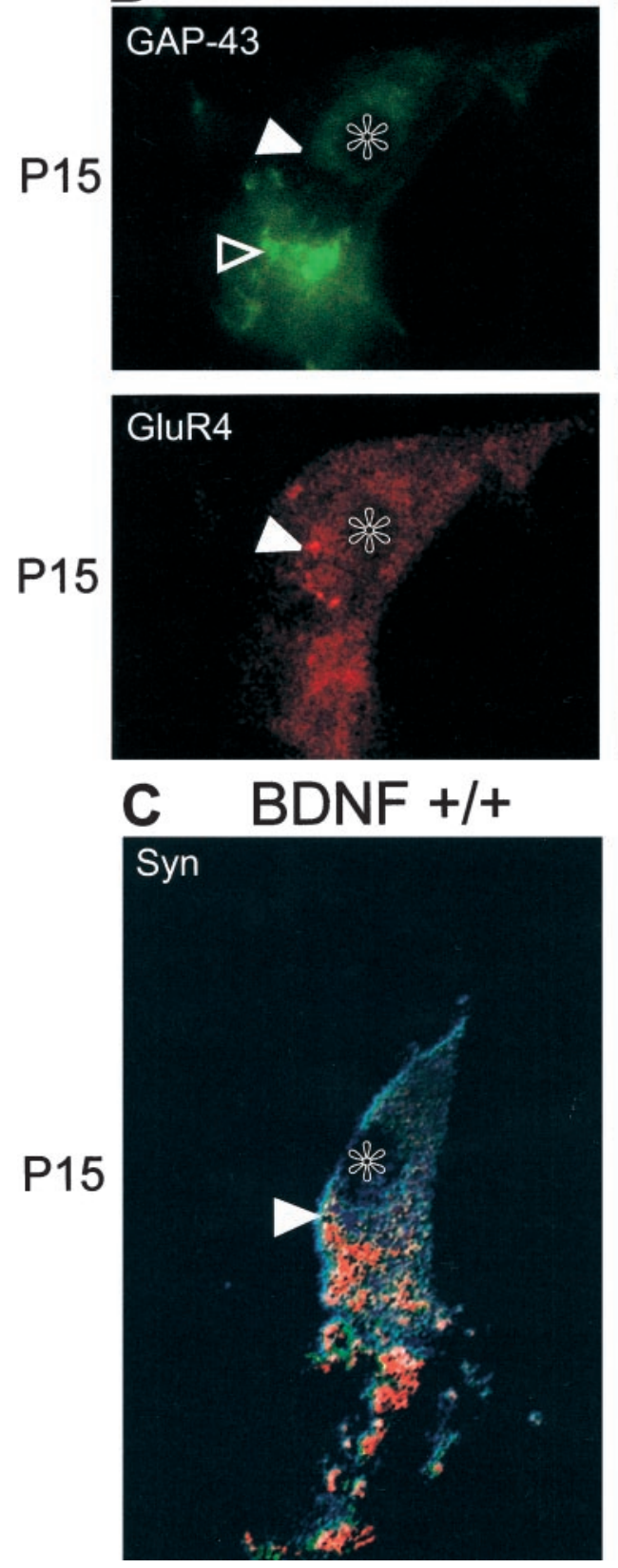

BDNF -/-
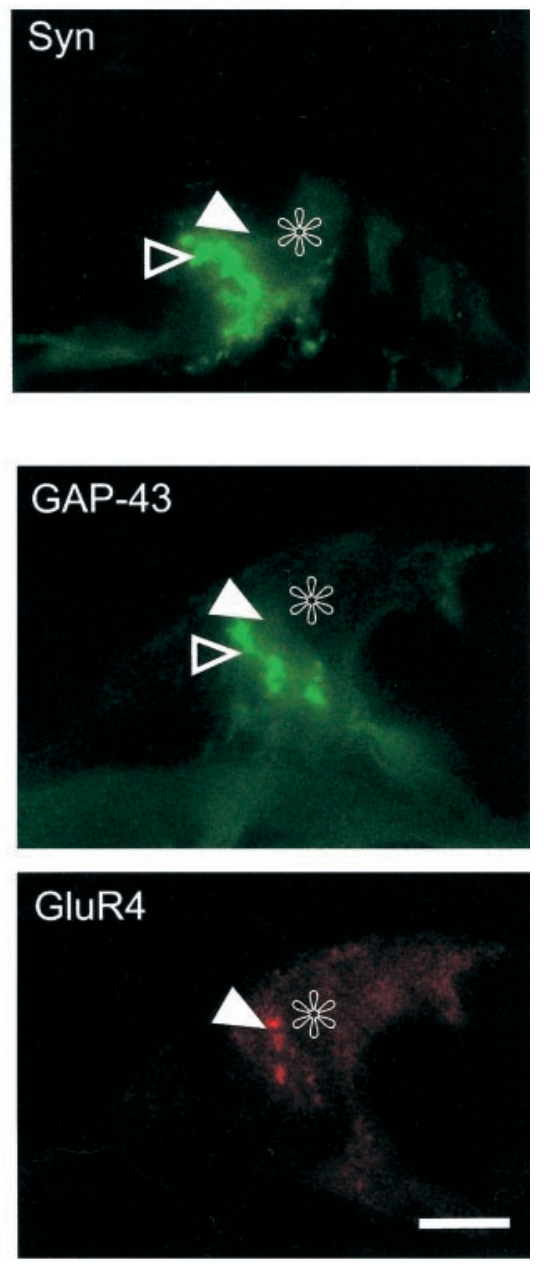

BDNF -/-

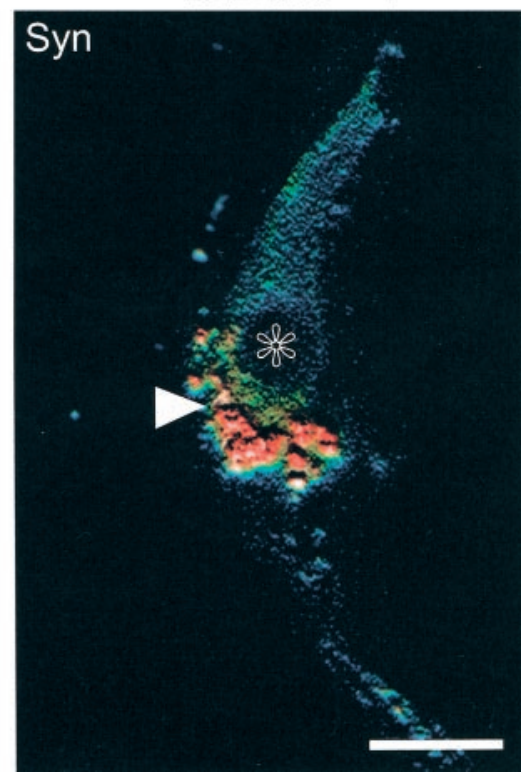

Figure 8. Innervation of inner hair cells in control and $\mathrm{BDNF}$ gene-deleted mice in the midbasal turn at $\mathrm{P} 4$ and $\mathrm{P} 15$ analyzed by immunohistochemistry. $A$, Staining of the immature synaptophysinimmunopositive efferent innervation at P4. Note the close localization of the efferent projections at the base of the IHCs in both mice specimens (compare the distance of the arrowhead and asterisk in BDNF $+/+$ and $-/-$ mice at P4). $B$, Immunostaining of the afferent and efferent fibers by double-labeling at P15. GluR4-immunopositive afferent nerve endings were observed at the base of inner hair cell of $\mathrm{BDNF}+/+$ and $-/-$ mice (GluR4, filled arrowheads). In BDNF $+/+$ mice, GAP-43immunopositive presumptive LOC terminals (GAP-43, open arrowheads) were localized in a distance to the base of the inner hair cell (filled arrowheads). In contrast to control, in $\mathrm{BDNF}-/-$ mice, GAP-43-immunopositive presumptive LOC terminals (GAP-43, open arrowheads) were observed at the hair cell base ( filled arrowheads), indicating the persistence of axosomatic LOC synapses in BDNF $-/-$ mice. Note the distance between the two arrowheads in BDNF $+/+$ and $-/-$ mice. Asterisks mark the hair cell nucleus. The experiment was repeated in triplicate with similar results. $C$, Comparison of efferent innervation of inner hair cells in control and BDNF gene-deleted mice at P15 by laser scanning confocal microscopy using an antisynaptophysin antibody. In BDNF +/+ mice, a scattered elongated synaptophysin-immunopositive pattern was observed below the inner hair cell base ( filled arrowheads), whereas in BDNF -/- the synaptophysin staining was concentrated at the base of inner hair cell (filled arrowheads). Differences in colors from blue to green to red mirror an intensity gradient of immunoreactivity. Asterisks mark the hair cell nucleus. Scale bars, $10 \mu \mathrm{m}$. when compared with controls, the synaptogenesis of MOC efferents in BDNF mutant mice occurs with a delay of several days (Fig. 6), suggesting that BDNF, nevertheless, has an indirect or redundant effect on this process. Because the synaptogenesis of
MOC efferents and the reorganization of synaptic specializations in OHCs in BDNF - /- mice occurred with the same delay, these processes seem causally related and timed by BDNF. Recently, a transient appearance of the trkB full-length receptor in hair cells 
was suggested as influencing the reorganization of synaptic specializations (Knipper et al., 1996, 1997). In support of this hypothesis, we here observed the upregulation of the trkB ligand BDNF coincident with the transient receptor expression in hair cells.

\section{Afferent type I collaterals to outer hair cells}

The retraction of transitory afferent type I collaterals from OHCs (Echteler, 1992; Knipper et al., 1997) and IHCs (Sobkowicz, 1992) during the first postnatal week coincides with the downregulation of BDNF from hair cells shortly after birth, as observed in the present study (Fig. 2, P3). The absence of afferent type I collaterals in BDNF null mutants below OHCs (Fig. 7, GluR2/3) implies that these fibers are BDNF-dependent and, as a consequence, retract in control animals when BDNF disappears from target hair cells after P1. Considering the predicted differential trophic gradient of BDNF and NT-3 along the tonotopic axis of the cochlea (Bianchi et al., 1996; Fritzsch et al., 1997), our data cannot exclude the possibility that BDNF might have fewer effects on afferent type I collaterals in basal than in the apical cochlea turn, because GluR2/3-immunoreactive afferent type I collaterals retract from basal cochlea turns before birth. In addition, further studies are required for analyzing whether collaterals to IHCs are BDNF-dependent as well, and, as a result, become reduced in number because of the disappearance of BDNF from inner hair cells. The retraction of BDNF-dependent afferent type I collaterals as a consequence of the disappearance of BDNF from the target outer hair cells suggests a new withdrawal mechanism for these fibers. This contrasts with the earlier notion that afferent type I collaterals retract because of the competition with innervating afferent type II or MOC efferents (Pujol, 1986; Sobkowicz, 1992).

\section{Afferent type II fibers to outer hair cells}

In agreement with previous studies (Ernfors et al., 1995; Bianchi et al., 1996; Fritzsch et al., 1997), we report the absence of afferent type II fibers in BDNF gene-deleted mice (Fig. 7), thus confirming BDNF dependency of these fibers. Afferent type II fibers were, however, still noted in basal cochlea turns in BDNF $-/-$ mice (data not shown), in line with the absence of BDNF in these cochlea turns and consistent with the predicted BDNF gradient along the tonotopic axis of the cochlea (Bianchi et al., 1996; Fritzsch et al., 1997). Thus, the data indicate a cochlear gradient in the BDNF dependency of afferent type II fibers.

After BDNF downregulation in target hair cells in control animals, single spiral ganglion neurons synthesize their own BDNF (Figs. 2, 4). This suggests that BDNF-dependent afferent type II fibers may grow and mature through an autocrine mechanism until BDNF is supplied again by target and supporting cells. A transient autocrine loop for neurotrophin action during development has also been proposed for other sensory neurons (Schecterson and Bothwell, 1992; for review, see Davies and Wright, 1995).

At the time when BDNF reappears in outer hair cells and supporting cells (Fig. 2, P6), afferents type II make synaptic contacts with OHCs (Hafidi and Romand, 1989; Echteler, 1992; Knipper et al., 1997). The expression of BDNF in supporting cells as pillar, Deiters', and border cells, in addition to hair cells during this period, may either serve to transiently enlarge the target field and/or to ensure the innervation of supporting cells (Burgess et al., 1997). Because it has been suggested that BDNF is involved in the maturation of the neuromuscular synapses and in the development of synapses in the visual system (for review, see Lu and Figurov, 1997), we propose that in the auditory system, target-derived BDNF, in addition to supporting cell-derived BDNF, may induce synaptogenesis of afferent type II fibers. The disappearance of BDNF from OHCs and pillar cells subsequent to presumptive synaptogenesis of afferent type II fibers at approximately P8-P10 (Fig. 2) may imply that, as in other systems (Acheson et al., 1995; Davies and Wright, 1995), these fibers may lose their BDNF dependency again after maturation of the innervation pattern. This process would occur later for the innervation pattern of Deiters' cells.

\section{Efferent fibers to inner hair cells}

In conjunction with a maximum BDNF expression in spiral ganglion neurons (Fig. 2, P5), BDNF was found in axons and dendrites, suggesting that BDNF may be transported and released by axons and dendrites, as has been shown for visual projections by von Bartheld et al. (1996). BDNF was localized in afferent dendrites when LOC efferents form axodendritic contacts with afferent type I projections (Lenoir et al., 1980; Pujol, 1986; Knipper et al., 1995). Because in BDNF null mutant mice LOC efferents fail to form axodendritic contacts (Fig. 8), we assume that BDNF is involved in the reorganization of LOC projections. Thus, we propose that BDNF, which is synthesized, transported, and released by afferents, may attract LOC fibers and stabilize new axodendritic synapses. A similar role of BDNF for the stabilization of synapses has been shown for neuromuscular junctions (Kwon and Gurney, 1996). The presence and persistence of axosomatic contacts of LOC efferents in BDNF gene-deleted mice (Fig. 8) indicate that other factors besides BDNF may regulate the formation of axosomatic contacts or that $\mathrm{BDNF}$ is redundant for the guidance and maintenance of LOC efferents. In control animals, however, the decline of BDNF from IHCs observed at approximately P1 may cause the retraction of BDNF-dependent LOC efferents, as has been suggested by Wheeler et al. (1994).

\section{Conclusion}

In conclusion, and for the first time, the data in the present study suggest that, before the onset of auditory function, BDNF may have a controlling role for the refinement of the innervation pattern. In particular, the retraction of fibers may be caused by the disappearance of BDNF from target hair cells, whereas the successive upregulation of BDNF in hair cells, supporting cells, and spiral ganglion cells appears to be related to the formation of new synaptic contacts. Indeed, the innervation density and patterning have been shown to be influenced by the experimental modulation of the BDNF level (Cohen-Cory and Fraser, 1995; Causing et al., 1997). Because the synthesis of neurotrophins is regulated by neuronal activity (for review, see Thoenen, 1995) and neuronal activity is increased by neurotrophins (Lohof et al., 1993; Knipper et al., 1993a,b, 1994a,b; Leßmann et al., 1994; Kang and Schuman, 1995; Figurov et al., 1996), it has been suggested that a reciprocal interaction between neurotrophins and neuronal activity may be involved in the innervation patterning after the onset of the function of sensory organs (for review, see Shatz, 1996; Knipper and Rylett, 1997). Before the onset of visual function, spontaneous NMDA-mediated activity of retinal ganglion cells is assumed to regulate the refinement of early neuronal connections in the visual system (for review, see Shatz, 1996). Because NMDA receptors have been localized during transient trkB (Knipper et al., 1997) and BDNF expression (present study), coincident to the fiber rearrangement in the 
developing cochlea, the next challenge will be to investigate whether or not BDNF and NMDA-mediated spontaneous activity act in concert to determine the refinement of fibers before the transmission of sensory information.

\section{REFERENCES}

Acheson A, Conover JC, Fandl JP, DeChiara TM, Russell M, Thandani A, Sqinto SP, Yancopoulos GD, Lindsay RM (1995) A BDNF autocrine loop in adult sensory neurons prevents cell death. Nature 374:450-453.

Antonini A, Stryker MP (1993) Rapid remodeling of axonal arbors in the visual cortex. Science 260:1819-1821.

Barde YA (1989) Trophic factors and neuronal survival. Neuron 2:1525-1534

Berglund AM, Ryugo DK (1986) A monoclonal antibody labels TII neurons of the spiral ganglion. Brain Res 383:327-332.

Bianchi L, Conover JC, Fritzsch B, DeChiara T, Lindsay RM, Yancopoulos GD (1996) Degeneration of vestibular neurons in late embyogenesis of both heterozygous and homozygous BDNF null mutant mice. Development 122:1965-1973.

Bothwell M (1991) Keeping track of neurotrophin receptors. Cell 65:915-918.

Burgess BJ, Adams JC, Nadol JB (1997) Morphological evidence for innervation of Deiters' and Hensen's cells in the guinea pig. Hear Res 108:74-82.

Cabelli RJ, Hohn A, Shatz CJ (1995) Inhibition of ocular dominance column formation by infusion of NT-4/5 or BDNF. Science 267:1662-1666.

Causing CG, Gloster A, Aloyz R, Bamji SX, Chang E, Fawcett J, Kuchel G, Miller FD (1997) Synaptic innervation density is regulated by neuron-derived BDNF. Neuron 18:257-267.

Chao MV (1994) The p75 neurotrophin receptor. J Neurobiol 25:1373-1385.

Cohen-Cory S, Fraser SE (1995) Effects of brain-derived neurotrophic factor on optic axon branching and remodelling in vivo. Nature 378:192-196.

Cramer KS, Sur M (1995) Activity-dependent remodeling of connections in the mammalian visual system. Curr Opin Neurobiol 5:106-111.

Davies AM, Wright EM (1995) Neurotrophic factors. Neurotrophin autocrine loops. Curr Biol 5:723-726.

Echteler SM (1992) Developmental segregation in the afferent projections to mammalian auditory hair cells. Proc Natl Acad Sci USA 89:6324-6327.

Ernfors P, Van De Water T, Loring J, Jaenisch R (1995) Complementary roles of BDNF and NT-3 in vestibular and auditory development. Neuron 14:1153-1164.

Figurov A, Pozzo-Miller LD, Olafsson P, Wang T, Lu B (1996) Regulation of synaptic responses to high-frequency stimulation and LTP by neurotrophins in the hippocampus. Nature 381:706-709.

Fritzsch B, Silos Santiago I, Bianchi LM, Farinas I (1997) The role of neurotrophic factors in regulating the development of inner ear innervation. Trends Neurosci 20:159-164.

Hafidi A, Romand R (1989) First appearance of type II neurons during ontogenesis in the spiral ganglion of the rat. An immunocytochemical study. Brain Res Dev Brain Res 48:143-149.

Hockfield S, Kalb RG (1993) Activity-dependent structural changes during neuronal development. Curr Opin Neurobiol 3:87-92.

Kang HJ, Schuman EM (1995) Neurotrophin-induced modulation of synaptic transmission in the adult hippocampus. J Physiol (Paris) 89:11-22.

Knipper M, Rylett RJ (1997) A new twist in an old story: the role for crosstalk of neuronal and trophic activity. Neurochem Int 31:659-676.

Knipper M, Beck A, Rylett RJ, Breer H (1993a) Neurotrophin-induced cAMP and IP3 responses in PC12 cells. FEBS Letters 324:147-152.

Knipper M, Beck A, Rylett RJ, Breer H (1993b) Neurotrophin-induced second messenger responses in rat brain synaptosomes. NeuroReport 4:483-486.

Knipper M, Leung LS, Zhao D, Rylett RJ (1994a) Short-term modulation of glutamatergic synapses in adult rat brain hippocampus by nerve growth factor. NeuroReport 5:2433-2436.

Knipper M, Berzaghi DP, Blöchl A, Breer H, Thoenen H, Lindholm D (1994b) Positive feedback between acetylcholine and the neurotrophins nerve growth factor and brain-derived neurotrophic factor in the rat hippocampus. Eur J Neurosci 6:668-671.

Knipper M, Zimmermann U, Rohbock K, Köpschall I, Zenner HP (1995) Synaptophysin and GAP-43 proteins in efferent fibers of the inner ear during postnatal development. Brain Res Dev Brain Res 89:73-86.

Knipper M, Zimmermann U, Rohbock K, Köpschall I, Zenner HP (1996) Expression of neurotrophin receptor trkB in rat cochlear hair cells at time of rearrangement of innervation. Cell Tissue Res 283:339-353.

Knipper M, Köpschall I, Rohbock K, Köpke AKE, Bonk I, Zimmermann U, Zenner HP (1997) Transient expression of NMDA receptors during rearrangement of AMPA-receptor-expressing fibers in the developing inner ear. Cell Tissue Res 287:23-41.

Korte M, Carroll P, Wolf E, Brem G, Thoenen H, Bonhoeffer T (1995) Hippocampal long-term potentiation is impaired in mice lacking brainderived neurotrophic factor. Proc Natl Acad Sci USA 92:8856-8860.

Kwon YW, Gurney ME (1996) Brain-derived neurotrophic factor transiently stabilizes silent synapses on developing neuromuscular junctions. J Neurobiol 29:503-516.

Lenoir M, Shnerson A, Pujol R (1980) Cochlear receptor development in the rat with emphasis on synaptogenesis. Anat Embryol (Berl) 160:253-262.

Leßmann V, Gottmann R, Heumann R (1994) BDNF and NT-4/5 enhance glutamatergic synaptic transmission in cultured hippocampal neurons. NeuroReport 6:21-25.

Lohof AM, Ip NY, Poo MM (1993) Potentiation of developing neuromuscular synapses by the neurotrophins NT-3 and BDNF. Nature 363:350-353.

Lu B, Figurov A (1997) Role of neurotrophins in synapse development and plasticity. Rev Neurosci 8:1-12.

Meister M, Wong RO, Baylor DA, Shatz CJ (1991) Synchronous bursts of action potentials in ganglion cells of the developing mammalian retina. Science 252:939-943.

Montcouquiol M, Valat J, Travo C, Sans A (1998) A role for BDNF in early postnatal rat vestibular epithelia maturation: implication of supporting cells. Eur J Neurosci 10:598-606.

Penn AA, Wong RO, Shatz CJ (1994) Neuronal coupling in the developing mammalian retina. J Neurosci 14:3805-3815.

Pirvola U, Arumae U, Moshnyakov M, Palgi J, Saarma M, Ylikoski J (1994) Coordinated expression and function of neurotrophins and their receptors in the rat inner ear during target innervation. Hear Res 75:131-144.

Pujol R (1986) Synaptic plasticity in the developing cochlea. In: The biology of change in otolaryngology (Ruben RW, van De Water TR, Rubel EW, eds) pp 47-54. Amsterdam: Elsevier.

Schecterson LC, Bothwell M (1992) Novel roles for neurotrophins are suggested by BDNF and NT-3 expression in developing neurons. Neuron 9:449-463.

Shatz CJ (1996) Emergence of order in visual system development. J Physiol (Paris) 90:141-150.

Sobkowicz HM (1992) The development of innervation in the organ of Corti. In: Development of auditory and vestibular systems, Vol II (Romand R, ed), pp 59-100. Amsterdam: Elsevier.

Thoenen H (1995) Neurotrophins and neuronal plasticity. Science 270:593-598.

Towbin H, Stachelin T, Gordon J (1979) Electrophoretic transfer of proteins from polyacrylamide gels to nitrocellulose sheets. Procedure and some applications. Proc Natl Acad Sci USA 76:4350-4354.

Van Essen DC, Gordon H, Soha JM, Fraser SE (1990) Synaptic dynamics at the neuromuscular junction: mechanisms and models. J Neurobiol 21:223-249.

von Bartheld CS, Byers MR, Williams R, Bothwell M (1996) Anterograde transport of neurotrophins and axodendritic transfer in the developing visual system. Nature 379:830-833.

Wang T, Xie K, Lu B (1995) Neurotrophins promote maturation of developing neuromuscular synapses. J Neurosci 15:4796-4805.

Wheeler EF, Bothwell M, Schecterson LC, von Bartheld CS (1994) Expression of BDNF and NT-3 mRNA in hair cells of the organ of Corti: quantitative analysis in developing rats. Hear Res 73:46-56.

Ylikoski J, Pirvola U, Moshnyakov M, Palgi J, Arumae U, Saarma M (1993) Expression patterns of neurotrophin and their receptor mRNAs in the rat inner ear. Hear Res 65:69-78.

Ylikoski J, Pirvola U, Virkkala J, Suvanto P, Liang XQ, Magal E, Altschuler R, Miller JM, Saarma M (1998) Guinea pig auditory neurons are protected by glial cell line-derived growth factor from degeneration after noise trauma. Hear Res 124:17-26.

Zhou XF, Rush RA (1996) Endogenous brain-derived neurotrophic factor is anterogradely transported in primary sensory neurons. Neuroscience 74:945-953. 